\title{
Factors influencing knowledge and practices for prevention of bovine tuberculosis amongst workers at Abattoir in Karachi
}

\author{
Mujeeb-ur-Rahman Memon ${ }^{1 *}$, Jahan Ara Baloch ${ }^{2}$, Tanveer Ali
}

Fazlani $^{1}$, Jamila soomro ${ }^{3}$, Saeed Ahmed Soomro ${ }^{3}$, Panah Munir

Shahwani ${ }^{4}$, Aimal Khan Kasi ${ }^{4}$ and Raza Shah Kakar ${ }^{4}$

1. Department of Veterinary Medicine-Pakistan

2. Pathology Section, Central Veterinary Diagnostic Laboratory, Tandojam-Pakistan

3. Department of Veterinary Physiology and Biochemistry-Pakistan

4. Livestock and Dairy Development Department Balochistan-Pakistan

*Corresponding author's email: drmujeebsau@gmail.com

Citation

Mujeeb-ur-Rahman Memon, Jahan Ara Baloch, Tanveer Ali Fazlani, Jamila soomro, Saeed Ahmed Soomro, Panah Munir Shahwani, Aimal Khan Kasi and Raza Shah Kakar. Factors influencing knowledge and practices for prevention of bovine tuberculosis amongst workers at Abattoir in Karachi. Pure and Applied Biology. Vol. 9, Issue 2, pp1497-1503. http://dx.doi.org/10.19045/bspab.2020.90155

\begin{tabular}{llll}
\hline \hline Received: 11/12/2019 & Revised: 25/02/2020 & Accepted: 06/03/2020 & Online First: 10/03/2020 \\
\hline
\end{tabular}

\section{Abstract}

Present study was designed to investigate the level of knowledge and practices for prevention of Bovine Tuberculosis amongst workers at two abattoirs in Karachi. The Data was collected from the herdsman and abattoirs worker at two abattoirs namely City Abattoir Cattle Colony in Landhi and New Karachi slaughterhouse (kamailas) which were working under Karachi Municipal Corporation.120 abattoir workers were interviewed and information was obtained, while frequency counts, percentages and independent sample ttest were used to analyze data. Data indicates the ratio of respondent including herd man and abattoirs workers having no knowledge to those having knowledge was 85:15 Statistical analysis revealed that level of education is potential factor influencing risk of BTB zoonoses amongst abattoir workers Educated respondent were having twice higher knowledge than un educated (OR 0.454, 95\% CI 0.236-0.872 P < 0.024).Educated workers demonstrated three time higher practices for preventive measures than non-educated (OR 0.607, 95\% CI 0.335$1.102, \mathrm{P}<0.133)$. Despite having awareness amongst abattoirs worker there was lower level of good practices It was therefore concluded that along with launching awareness program from government organizations it must be ensure practical application of WHO and FAO guidelines for TB free world under one health program ending 2030.

Keywords: Abattoir; Safety measures; Meat; Butchers

\section{Introduction}

Bovine tuberculosis (BTB) is an important zoonotic disease. Especially in developing countries, its harmful is still serious caused by Mycobacterium tuberculosis. Amongst domestic animals cattle is the primary host of the $M$. bovis from where it is transmitted to the human and causes zoonotic TB [1]. Millions of deaths in human are being reported. As per data collected by World Health Organization (WHO) worldwide, during 2015about 10.4 million people 
developed T.B due to $M$. bovis and it was ranked amongst top 10 causes death. In 2016, an estimated 147,000 new human cases of zoonotic TB and 12,500 deaths due to the disease occurred globally [2].

Transmission of $M$. bovis to human may occur either directly by use of contaminated animal products such as milk and meat [3] or direct contact with or inhalation of the bacteria in air exhaled by infected animals during the course of slaughter [4]. M. bovis is frequently isolated from various animal organs/tissues such as lesions in the lungs and lymph nodes at slaughterhouses gestures that the disease can spread through both direct and indirect modes to human [5]. Even though direct transmission from animals to humans through the air is thought to be rare, $M$. bovis can be transmitted directly from person to person when people with the disease in their lungs cough or sneeze [6]. M. bovis has been incriminated together with MTC species as the cause of tuberculous lymphadenitis in humans [7]. Occupational exposures to $M$. bovis have been reported in many countries including Australia [8].

Karachi is thickly populated metropolitan city of Pakistan. There are officially two government approved and registered abattoirs. One is located in the Cattle Colony in Landhi and other at New Karachi where about 1,200 cows and buffaloes and around 3,000 to 4,000 smaller animals, such as goats and sheep are slaughtered on an average each day. Since the knowledge of potential risk factors of transmission of bovine tuberculosis and its preventive measures by occupation worker in slaughter house plays an important role in controlling it transmission amongst worker and also reduce implication health risk to consumers of meat. Present study was conducted assess socio demography level of awareness and practices of safety measures for preventing risk of bovine tuberculosis by occupational workers working at Abattoirs of Karachi

\section{Material and methods \\ Study site and population}

The study was carried out at two abattoirs namely City Abattoir Cattle Colony in Landhi and New Karachi slaughterhouse (kamailas) which were working Karachi Municipal Corporation. A whole of a hundred twenty $(\mathrm{n}=120)$ employee working at abattoirs were chosen as respondents furnishing data for the study.

\section{Study design}

This study primarily based on quantitative questionnaires to reply questions on focus and workout with suppose about to hygiene among abattoir workers. Awareness and attention have been decided by way of the use of structured interview and through direct observations of the hygienic frame and practices through abattoir workers.

\section{Data collection}

Data was collected from the respondent (abattoir workers) through direct interview and information was recorded on pre structured questionnaire. The questionnaire consisted of three sections; 1) Sociodemographic socio-demographic characteristics such as age, gender, level of education, experience; 2) knowledge of awareness safety practices (workers self and slaughter house); 3) Utilization or practice of safety measures (worker self and slaughter house. Respondent answer was recorded as "yes", "no"

\section{Statistical analysis}

Data collected was transferred in excel sheet and analyzed using Excel Stat statistical software. The odd values and ratios were calculated to determine difference between the strength of groups in variables. Probability values were also calculated at $95 \%$ CI to determine the significance levels.

\section{Results}

\section{Socio-demographic characteristics of respondents}

The data was collected from two abattoirs first city abattoir cattle colony and second new Karachi slaughter house (kamilas). A total of 120 respondents of first including 
47 herdsmen (39.1\%) and 73 abattoir worker $(60.8 \%)$ were interview through pre-prepared survey questionnaire. The data reveals that amongst respondents interviewed at both abattoirs percent of highest frequency of respondent were aged between 21-40 years (58\%). Amongst workers higher number was having no formal education i.e. 71 (59.17) as compare to those having formal education 49 (40.83\%).Majority of worker were married and having experience of above 20 years (Table 1$)$.

Table 1. Distribution of respondents by their socio-economic characteristics

\begin{tabular}{|c|c|c|}
\hline \multirow{2}{*}{ Variable } & \multicolumn{2}{|c|}{ Abattoir $(n=120)$} \\
\hline & Frequency & Percentage \\
\hline \multicolumn{3}{|c|}{ Age } \\
\hline$\leq 20$ & 7 & 5.83 \\
\hline $21-40$ & 58 & 48.33 \\
\hline $41-60$ & 55 & 45.84 \\
\hline \multicolumn{3}{|l|}{ Level of education } \\
\hline No formal education & 71 & 59.17 \\
\hline Formal education & 49 & 40.83 \\
\hline \multicolumn{3}{|c|}{ Marital status } \\
\hline Married & 72 & 60.0 \\
\hline Single & 48 & 40.0 \\
\hline \multicolumn{3}{|l|}{ Years of experience } \\
\hline lessorequal10 & 12 & 10.0 \\
\hline $11-20$ & 42 & 35.0 \\
\hline $21-30$ & 66 & 55.0 \\
\hline \multicolumn{3}{|l|}{ Occupation type } \\
\hline Herdsman & 47 & 39.17 \\
\hline Abattoir workers & 73 & 60.83 \\
\hline
\end{tabular}

Demographic factors associated the knowledge of zoonotic risk of BTB

Results shown in table 2 indicates the ratio of respondent including herd man and abattoir workers having no knowledge to those having knowledge was 85:15 Amongst different age group worker those who had knowledge about BTB prevention was higher i.e. between 41-60 year (13.3). There was nearly similar percent of respondent with no education and education. Knowledgeable respondent were higher in married group as compare to unmarried. A positive correlation was recorded in experience of work with knowledge. There was significant difference between the age group 21-40 and 41-60 years. Later one had about twice higher level of knowledge than first (OR $0.320,96 \%$ CI 0.167-0.612, $\mathrm{P}>0.001)$. Similar trend was observed between non educated and educated respondent.
Educated respondent were twice higher knowledge than no educated (OR 0.454, $95 \%$ CI $0.236-0.872 \quad \mathrm{P}<0.024)$. Respondent with work experience less than 10 years were more knowledgeable compared to those with 11-20 and 21-30 years work (OR 0.702, 0.216-2.276, $\mathrm{P}<$ 0.769 ).

Demographic factors associated the practices to prevent zoonotic risk of BTB

Table 3 shows the data collected regarding quality of practice. Respondents including herdsman and abattoir workers 31.33 percent demonstrated good practice. Amongst respondents of different age group, levels of education and work experience on an average 33 percent were having positive response for practices about preventive measure for zoonotic BTB. The data revealed significant difference between different age groups. 
Those at age of 41-60 years demonstrated good practice higher than between 21-40 years (OR 0.462, 0.236-0.901, $\mathrm{P}<0.032$ ). Educated workers demonstrated three time higher practices for preventive measures than non-educated (OR 0.607, 95\% CI
0.335-1.102, $\quad \mathrm{P}<\quad$ 0.133).Respondents having experience of 11-20 years appeared to follow the preventive measure more efficiently than rest of groups (OR 0.832, 95\% CI 0.418-1.655, P<0.727).

Table 2. Factors influencing levels of knowledge about zoonotic TB prevention amongst abattoir workers in Karachi $(\mathbf{N}=120)$

\begin{tabular}{|c|c|c|c|}
\hline Variable & $\begin{array}{c}\text { Not Knowledgeable } \\
\mathbf{N}(\%) \\
\end{array}$ & $\begin{array}{c}\text { Knowledgeable } \\
\text { N (\%) }\end{array}$ & OR, 95\% CI, p-value \\
\hline \multicolumn{4}{|c|}{ Age } \\
\hline$\leq 20$ & $4(3.33)$ & $3(2.5)$ & $0.744,0.163-3.396,1.000$ \\
\hline $21-40$ & 47(39.17) & $11(9.17)$ & $0.157,0.076-0.322,1.000$ \\
\hline $41-60$ & $39(32.5)$ & $16(13.33)$ & $0.320,0.167-0.612,0.001$ \\
\hline \multicolumn{4}{|c|}{ Level of education } \\
\hline $\begin{array}{l}\text { No formal } \\
\text { education }\end{array}$ & $53(44.17)$ & $18(15.0)$ & $0.223,0.120-0.414,0.000$ \\
\hline Formal education & $32(26.66)$ & $17(14.17)$ & $0.454,0.236-0.872,0.024$ \\
\hline \multicolumn{4}{|c|}{ Marital status } \\
\hline Married & $62(51.67)$ & $10(8.33)$ & $0.085,0.041-0.178,0.000$ \\
\hline Single & $41(34.17)$ & $7(5.83)$ & $0.119,0.051-0.280,0.000$ \\
\hline \multicolumn{4}{|c|}{ Years of experience } \\
\hline Less or equal 10 & $7(5.83)$ & $5(4.17)$ & $0.702,0.216-2.276,0.769$ \\
\hline $11-20$ & $29(24.17)$ & $13(10.83)$ & $0.381,0.187-0.777,0.010$ \\
\hline $21-30$ & $55(45.83)$ & $11(9.17)$ & $0.119,0.058-0.222,0.000$ \\
\hline \multicolumn{4}{|c|}{ Occupation type } \\
\hline Herdsman & $40(33.33)$ & $7(5.83)$ & $0.124,0.053-0.291,0.000$ \\
\hline Abattoir workers & $62(51.67)$ & $11(9.17)$ & $0.094,0.046-0.193,0.000$ \\
\hline
\end{tabular}

Table 3. Factors influencing levels of practices about zoonotic TB prevention amongst abattoir workers in Karachi $(\mathbf{N}=120)$

\begin{tabular}{|c|c|c|c|}
\hline Variable & Poor practice n (\%) & $\begin{array}{c}\text { Good practice n } \\
(\%)\end{array}$ & \multirow{2}{*}{ OR, 95\% CI, p-value } \\
\hline \multicolumn{3}{|c|}{ Age } & \\
\hline$\leq 20$ & $6(42.0)$ & $6(5.0)$ & $1.000,0.313-3.193,1.000$ \\
\hline $21-40$ & $42(35.0)$ & $20(16.67)$ & $0.371,0.202-0.683,0.002$ \\
\hline $41-60$ & $30(25.0)$ & $16(13.33)$ & $0.462,0.236-0.901,0.032$ \\
\hline $\begin{array}{c}|c| \\
\text { No formal } \\
\text { education }\end{array}$ & $45(37.5)$ & $16(13.33)$ & \multirow{2}{*}{$0.256,0.135-0.488,0.000$} \\
\hline Formal education & $35(29.17)$ & $24(20.0)$ & $0.607,0.335-1.102,0.133$ \\
\hline \multicolumn{3}{|c|}{ Marital status } & $0.169,0.088-0.323,0.000$ \\
\hline Married & $55(45.83)$ & $15(12.5)$ & $0.240,0.118-0.488,0.000$ \\
\hline Single & $38(31.67)$ & $12(10.0)$ & $0.706,0.310-1.609,0.534$ \\
\hline \multicolumn{3}{|c|}{ Years of experience } \\
\hline Less or equal 10 & $15(12.5)$ & $11(9.17)$ & $0.832,0.418-1.655,0.727$ \\
\hline 11-20 & $21(17.5)$ & $18(15.0)$ & $0.286,0.148-0.553,0.000$ \\
\hline $21-30$ & $40(33.33)$ & $15(12.5)$ & $0.550,0.294-1.030,0.084$ \\
\hline \multicolumn{3}{|c|}{ Occupation type } \\
\hline Herdsman & $32(26.67)$ & $20(16.66)$ & $0.247,0.133-0.459,0.000$ \\
\hline Abattoir workers & $50(41.67)$ & $18(15.0)$ \\
\hline
\end{tabular}




\section{Discussion}

Prevention and control of zoonotic risk of Bovine Tuberculosis amongst abattoir workers depends on their awareness about personal safety as well as slaughter procedures followed at abattoir. Practice for preventive measures taken by the working personals also plays an important role in reducing the risk of transmission of the BTB Keeping in view the heavy risks of zoonotic transmission of the BTB from animals to animal and animal to human leading to heavy economic losses of livestock as well as health hazard to human being in developing countries; WHO and FAO have launched road map for Bovine Tuberculosis under One Health Program [2].

Pakistan is one of the developing countries where majority of rural population have very close contact with animals due their animal housing system. Besides direct exposure of the animal to human there is contact of abattoir workers to the animals which are brought for slaughter. It was hypothesized that slaughter houses may be the site for high risk of transmission of BTB not only amongst the occupassional workers at abattoir but also to human population if preventive measures are not taken properly during slaughter procedures. Present study was designed to collect information regarding level of knowledge and Practice for preventive measures of zoonotic risk of BTB amongst abattoir workers and herdsman.

In present study only $15 \%$ including abattoir workers and herdsman were knowledgeable about BTB and on only 30 percent were found demonstrating practices to control zoonosis of BTB. [9] have reported that only $32.55 \%$ of the respondents (cattle owners) were aware of BTB and 23.25\% recognized that BTB is zoonotic. The results of current study also shows the similar trend as observed by [9] that very less number of respondents were aware of the BTB and its potential risk of transmission to contact persons. It has been indicated by. $[10,11]$ such low level of awareness about zoonotic risk of BTB and potential risk factor such as consumption of infected food poor sanitary measures may be threat to public health.

Awareness Personal safety measure amongst abattoir worker and its practice of is important to reduce risk of transmitting infection by contact with infected animals. During current study it was recorded that less than $40 \%$ workers had knowledge about their personal safety measure and amongst those only 2-3 percent were actually practicing. Wearing protective clothing within the slaughterhouse can protect meat handlers against directly transmitted zoonotic infections [12-14]. In present study the level of awareness and facilities available for sterilizing clothing, knives and other equipment by workers was less than 20 percent and only 0.6 percent practices were being carried out. [15] also reported that workers at abattoir were very less aware that they protect themselves from risk of getting and transmitting M.bovis infection if they do not handle meat with bare hands or injured hands. They emphasized that abattoir workers should be educated and aware about zoonotic transmission of BTB through electronic media. Similar conditions are prevailing in Pakistan.

The results of present study are in contrary to those of [16] who conducted study in Nigeria during 2015. They found that respondents were good in knowledge about zoonotic TB prevention but they avoid demonstrating good practice. The ration of good practice was almost half of the respondent knowledgeable. The livestock worker in developing countries does not care about their health $[17,18]$. In present study the responses of respondent towards knowledge was poor but amongst that good number were demonstrating practice to control zoonosis of BTB.

Education level significantly influences the knowledge and practices for prevention of zoonotic TB. Present study showed that formally educated respondents were more aware and were demonstrating good 
practices than those having no education. [18] have reported that education level of the abattoir worker imposes great impact on their level of knowledge and practices to prevent themselves from BTB. Similar reports have been made in Edo and Zamfara States, Nigeria [19, 20], Tanzania [22] as well as China [21], showing that education contributes significantly to knowledge and practices regarding TB. $[22,23]$ found that livestock owners and workers living in rural areas which are very far from the cities have either no or less access to educational institutes therefore could not get chance to obtain education thus remain illiterate. Similar conditions are seen in our country. Majority of workers at abattoir are either from rural areas or belongs to poor families and their socioeconomic conditions and liabilities does not allow them to get even primary education so remain uneducated and they have remained mostly neglected by the policy makers.

\section{Conclusion and recommendations}

It was concluded from the results of present studies that there is lapse of awareness amongst herdsman and abattoir worker for control and prevention measure of zoonotic TB. Therefore it is recommended that Livestock department with help of meat inspectors should educate the butchers and their associated helping personals about risk of BTB transmission from animals to workers. The must be provided training for proper personal safety measure and slaughter procedures. Meat inspectors must ensure that contaminated meat parts and visceral organs must be properly disposed off and incinerated to avoid exposure of infection to surrounding human population.

\section{Authors' contributions}

Conceived and designed the project: MR Memon, Performed the experiment: MR Memon, JA Baloch \& TA Fazlani, Analysed the data: MR Memon, J Soomro \& SA Soomro, Contributed in material, tools and field supervision: PM Shahwani,
AK Kasi \& RS Kakar, Helped in data analysis and proof reading of manuscript: MR Memon, J Soomro \& SA Soomro.

\section{Acknowledgments}

The authors also acknowledge to the authorities and staff of slaughterhouse Karachi, Pakistan, butchers, workers and labors of abattoir for their assistance and cooperation.

\section{References}

1. Cosivi O, Grange JM, Daborn CJ, Raviglione MC, Fujikura T \& Cousins $\mathrm{D}$ et al. (1998). Zoonotic tuberculosisdue to Mycobacterium bovis in developing countries. Emerg Infect Dis 4: 59-70.

2. WHO (2017). Zoonotic tuberculosis. World Health Organization (Accessed May 18, 2018). Available online at http://www.who.int/tb/zoonoticTB.pd.

3. Oliver SP, Boor KJ, Murphy SC \& Murinda SE (2009). Food safety hazards associated with consumption of raw milk. Foodborne Pathog Dis 6: 793-806.

4. Caffery JP (1994). Studies of bovine tuberculosis eradication programme in Europe. Vet Microbiol 40: 1-4.

5. Cadmus S, Palmer S, Okker M, Dale J, Gover K \& Smith N et al. (2006). Molecular analysis of human and bovine tubercle bacilli from a local setting in Nigeria. J Clin Microbiol 44:29-34.

6. CDC (2018). Centre for Disease Control. Mycobacterium bovis (bovine tuberculosis) in humans. Atlanta, Georgia, USAL: CDC Fact Sheet. Centers for Disease Control and Prevention (CDC); 2016. Available from: http://www.cdc.gov/tb/publications/factsheets/general/mbovis.pdf. [Last accessed on 2018 Jul 26].

7. Selim A, El-Haig $M$ \& Gaede $W$ (2014). Duplex real-time PCR assay targeting insertion elements IS1081 and IS6110 fordetection of Mycobacterium bovis in lymph nodes of cattle. Biotech Anim Husbandry 30: 45-59. 
8. Robinson P, Morris D \& Antic R (1988). Mycobacterium bovis as an occupational hazard in abattoir workers. Int Med J 18: 701-703.

9. Kemal J, Sibhat B, Abraham A, Terefe Y, Tulu KT, Welay K \& Getahun N (2019). Bovine tuberculosis in eastern Ethiopia: prevalence, risk factors and its public health importance. BMC Infectious Dis 19: 39.

10. Ameni G, Hewinson G, Aseffa A, Young D \& Vordermeier M (2008). Appraisal of interpretation criteria for the comparative intradermal tuberculin test fordiagnosis of tuberculosis in cattle in Central Ethiopia. Clin Vacc Immunol 15: 1272-1276.

11. Radostits OM, Gay CC, Hinchcliff KW \& Constable PD (2006). Diseases associated with Mycobacterium species. In: Veterinary Medicine. A Textbook of the Diseases of Cattle, Horses, Sheep, Pigs and Goats. 10thed. Edinburgh, London, New York, Oxford, Philadelphia, St Louis Sydney, Toronto, pp 1008-1010.

12. Nabukenya I, Kaddu-Mulindwa D \& Nasinyama GW (2013). Survey of Brucella infection and malaria among Abattoir workers in Kampala and Mbarara Districts, Uganda. BMC Public Health 13: 901.

13. FAO (2004). FAO Animal Production and Health. Rome: Food and Agriculture Organization of the United Nations.

14. Brown PD, McKenzie M, Pinnock M \& McGrowder D (2011). Environmental risk factors associated with leptospirosis among butchers and their associates in Jamaica. Int $J$ Occup Environ Med 2(1): 47-57.

15. Fekadu F, Beyene TJ, Beyi AF,Edao BM, Tufa TB, Woldemariyam FT \& Gutema FD (2018) RiskPerceptions and Protective BehaviorsToward Bovine Tuberculosis AmongAbattoir and Butcher Workers inEthiopia. Front Vet Sci 5: 169.

16. Adesokan HK, Akinseye VO \& Sulaimon MA (2018). Knowledge and practices about zoonotic tuberculosis prevention and associated determinants amongst livestock workers in Nigeria. PLoS ONE 13(6): e0198810.

17. Adesokan HK, Jenkins AO, Van Soolingen D \& Cadmus SIB (2019). Mycobacterium bovis infections in livestock workers in Ibadan, Nigeria: evidence of occupational exposure. Int J Tuberc Lung Dis 16(10): 1388-1392.

18. Khattak I, Mushtaq MH, Ahmad MUD, Khan MS \& Haider J (2016). Zoonotic tuberculosis in occupationally exposed groups in Pakistan. Occup Med 66(5): 371-376.

19. Tobin EA, Okojie PW \& Isah EC (2013). Community knowledge and attitude to pulmonary tuberculosis in ruralEdo State, Nigeria. Ann Afr Med 12(3): 148-154.

20. Ismail A \& Josephat P (2014). Knowledge and perception on tuberculosis transmission in Tanzania: Multinomial logistic regression analysis of secondary data. Tanzan $J$ Health Res 16(1).

21. Zhao Y, Ehiri J, Li D, Luo X \& Liet YY (2013). A survey of TB knowledge among medical students in SouthwestChina: is the information reaching the target. BMJ Open 3: e003454.

22. Zinsstag J \& Yosko I (2004). Pastoralisme nomade et sante au Tchad. Med Trop 64: 449-451.

23. Bechir M (2010). Etude epidemiologique de la malnutrition en milieu nomade au Tchad: diagnostic approched interventions. Dissertation, University of Basel, Switzerland. 